\title{
Vitamin D in follicular development and oocyte maturation
}

\author{
Fuhua $\mathrm{Xu}^{1}$, Shally Wolf ${ }^{2}$, O'ryai Green ${ }^{1,3}$ and Jing $\mathrm{Xu}^{1,2}$ \\ ${ }^{1}$ Division of Reproductive Endocrinology, Department of Obstetrics and Gynecology, School of Medicine, Oregon \\ Health \& Science University, Portland, Oregon, USA, ${ }^{2}$ Division of Reproductive \& Developmental Sciences, Oregon \\ National Primate Research Center, Oregon Health \& Science University, Beaverton, Oregon, USA and ${ }^{3}$ Department \\ of Biology, Portland State University, Portland, Oregon, USA
}

Correspondence should be addressed to J Xu; Email: xujin@ohsu.edu

\begin{abstract}
Vitamin D (VD) is a secosteroid hormone synthesized predominantly in the skin upon UV light exposure, which can also be obtained from dietary sources. In target cells, the bioactive VD binds to specific VD receptor to regulate downstream transcription of genes that are involved in a wide range of cellular processes. There is an increasing recognition that the proper physiological levels of VD are critical for optimizing reproductive potential in women. The direct VD action in the ovary was first suggested in the 1980s. Since then, research has attempted to determine the role of VD in follicular development and oocyte maturation in animal models and clinical settings. However, data published to date are inconclusive due to the complexity in VD metabolism and the fact that VD actions are pervasive in regulating physiological functions in various systems, including the reproductive, endocrine and nervous systems that control reproduction. This review summaries in vitro, in vivo, and clinical evidence regarding VD metabolism and signaling in the ovary, as well as VD-regulated or VD-associated ovarian follicular development, steroidogenic function, and oocyte maturation. It is suggested that adequate animal models are needed for well-controlled studies to unravel molecular mechanisms of VD action in the ovary. For clinical studies, follicular development and function may be evaluated more effectively in a relatively homogeneous patient population under a well-controlled experimental design. A comprehensive understanding of VD-regulated folliculogenesis and oogenesis will provide critical insight into the impact of VD in female reproductive health.

Reproduction (2021) 161 R129-R137
\end{abstract}

\section{Introduction}

Vitamin $\mathrm{D}(\mathrm{VD})$ is a secosteroid hormone synthesized from cholesterol predominantly in the skin upon UV light exposure, with an additional $\sim 10 \%$ being derived from dietary sources (Wagner et al. 2012). In addition to the well-known function of VD in regulating calcium absorption during osteogenesis, VD affects a wide range of cellular processes, including cell proliferation and differentiation, as well as apoptosis and inflammation (Verstuyf et al. 2010). There is an increasing recognition that VD plays a crucial role in female reproduction. The proper physiological levels of VD are considered critical for optimizing reproductive potential in women (Franasiak et al. 2017). For women of reproductive age, serum 25-hydroxyvitamin D3 (calcifediol) levels of $12.0-20.0 \mathrm{ng} / \mathrm{mL}$ and $<12.0 \mathrm{ng} / \mathrm{mL}$ are defined as VD insufficiency and deficiency, respectively (Zhao et al. 2012). Notably, VD insufficiency and deficiency have been a global health problem for the past few decades. People with increased skin melanin pigmentation, obesity, or abstinence from direct sun exposure are especially at high risk (Hossein-nezhad \& Holick 2013). Therefore, studies are conducted to unravel VD actions in reproductive organs in order to provide insight into benefits of VD in female reproductive health for clinical interventions.

Generally, vitamin D3 (cholecalciferol; animal source) and D2 (ergocalciferol; plant source) originated from the skin and diet are first converted to 25-hydroxyvitamin D3 in the liver via the action of vitamin D3 25-hydroxylase encoded by cytochrome P450 family 2 subfamily $\mathrm{R}$ polypeptide 1 (CYP2R1). The precursor is then converted to biologically active 1 $\alpha, 25$-dihydroxyvitamin D3 (calcitriol; VD3) in the kidney by cytochrome P450 family 27 subfamily B polypeptide 1 (CYP27B1) encoded 25-hydroxyvitamin D3-1 $\alpha$-hydroxylase (Bikle 2014). All forms of VD metabolites exist in the circulation. In target cells, the bioactive VD3 binds to a specific VD receptor (VDR), a DNA-binding transcription factor that is a member of the nuclear hormone receptor superfamily. VD3-VDR binding fastens the association between VDR and its heterodimeric co-receptor, retinoid $X$ receptor (RXR). This active signal transduction complex recognizes vitamin $\mathrm{D}$ responsive elements (VDREs) in the DNA sequence and regulates downstream gene transcription (Haussler et al. 2011).

The potential of direct VD action in the ovary was first suggested by a study in hens in the 1980s 
(Dokoh et al. 1983). As the female gonad, the ovary is responsible for producing steroid hormones to maintain endocrine function and generating competent oocytes for fertilization. Follicles are basic functional units in the ovary, each containing an oocyte surrounded by follicular cells. Ovarian folliculogenesis consists of primordial (dormant) follicle activation, preantral (primary and secondary) follicle growth, and antral (gonadotropin-responsive) follicle maturation to generate the preovulatory (Graafian) follicle. This dynamic follicular development process, along with the growth and maturation of enclosed oocyte, is controlled by local factors in combination with or mediating the actions of gonadotropic hormones (Gougeon 1996). Studies have attempted to determine the role of VD in folliculogenesis and oogenesis in animal models and clinical settings (Irani \& Merhi 2014). However, data published to date are inconclusive due to the complexity in VD metabolism and the fact that VD actions are pervasive in regulating physiological functions in various systems, including the reproductive, endocrine and nervous systems that control reproduction (Stumpf \& Denny 1989). The following sections summarize evidence regarding VD metabolism and signaling in the ovary, as well as VD-regulated or VD-associated ovarian follicular development, steroidogenic function, and oocyte maturation.

\section{VD and its signaling in the ovary \\ $V D$ sources for the ovarian follicles}

Vitamin D3 25-hydroxylase and 25-hydroxyvitamin D3-1 $\alpha$-hydroxylase are recognized as the hepatic and renal enzyme, respectively, because the circulating VD metabolites (25-hydroxyvitamin D3 and VD3) are predominantly synthesized in the liver and the kidney (Bikle 2014). However, research demonstrated that VD metabolism could also take place locally in the ovary. As summarized in Table 1, CYP2R1 mRNA encoding vitamin D3 25-hydroxylase was detected in human ovarian tissue using RT-PCR (Bièche et al. 2007). CYP27B1 mRNA and 25-hydroxyvitamin D3-1 $\alpha$-hydroxylase protein expression was identified by RT-PCR and Western blot, respectively, in human ovarian tissue and granulosa cells (GCs) from women receiving in vitro fertilization (IVF) treatment (Fischer et al. 2009). Consistently, both CYP2R1 and CYP27B1 were expressed by nonhuman primate (rhesus macaque) preantral and antral follicles, as determined by RNA sequencing and real-time PCR (Xu et al. 2016b, Xu et al. 2018). Therefore, follicular VD can be systemic and intraovarian origin.

A study in patients undergoing ovarian stimulation first showed that both VD metabolites, 25-hydroxyvitamin D3 and VD3, were present in the follicular fluid (Potashnik et al. 1992). Although levels of VD metabolites in the follicular fluid were relatively low, they correlated positively with those in the serum. Interestingly, when rhesus macaque antral follicles developed in vitro in VD-depleted conditions, follicular CYP2R1 mRNA levels were increased compared with size-matched in vivo-developed antral follicles (Xu et al. 2018). It appears that the reduced or loss of systemic VD supply could induce follicular VD biosynthesis for intraovarian VD production.

Table 1 Vitamin D metabolic enzyme and receptor expression in the ovary.

\begin{tabular}{|c|c|c|c|c|c|c|c|}
\hline Protein & Gene & Species & Materials & Methods & mRNA & Protein & References \\
\hline \multirow{2}{*}{$\begin{array}{l}\text { Vitamin D3 } \\
\text { 25-hydroxylase }\end{array}$} & CYP2R1 & Human & Ovarian tissue & RT-PCR & Yes & NA & Bièche et al. (2007) \\
\hline & & Rhesus macaque & $\begin{array}{l}\text { Isolated } \\
\text { follicles }\end{array}$ & RNAseq, RT-PCR & Yes & NA & Xu et al. (2016), (2018) \\
\hline \multirow[t]{2}{*}{$\begin{array}{l}\text { 25-hydroxyvitamin } \\
\text { D3-1 } \alpha \text {-hydroxylase }\end{array}$} & CYP27B1 & Human & $\begin{array}{l}\text { Ovarian } \\
\text { tissue, GCs }\end{array}$ & RT-PCR, WB & Yes & Yes & Fischer et al. (2009) \\
\hline & & Rhesus macaque & $\begin{array}{l}\text { Isolated } \\
\text { follicles }\end{array}$ & RNAseq, RT-PCR & Yes & NA & Xu et al. (2016b), (2018) \\
\hline \multirow[t]{9}{*}{ Vitamin D receptor } & $V D R$ & Fish & In vivo & Autoradiograph & NA & Yes & Bidman et al. (1997) \\
\hline & & Hen & Ovarian tissue & $\begin{array}{l}\text { Chromatography, sucrose } \\
\text { density gradient analysis, } \\
\text { saturation analysis }\end{array}$ & NA & Yes & Dokoh et al. (1983) \\
\hline & & Hen & $\begin{array}{l}\text { Isolated } \\
\text { follicles, } \\
\text { GCs }\end{array}$ & Real-time PCR, WB, IHC & Yes & Yes & Wojtusik \& Johnson (2012) \\
\hline & & Rat & Ovary & $\mathrm{IHC}$ & NA & Yes & Johnson et al. (1996) \\
\hline & & Goat & Ovary, GCs & Real-time PCR, WB, IHC & Yes & Yes & Yao et al. (2017) \\
\hline & & Pig & GCs & WB & NA & Yes & Herian et al. (2018) \\
\hline & & Rhesus macaque & $\begin{array}{l}\text { Ovary, } \\
\text { isolated } \\
\text { follicles }\end{array}$ & Real-time PCR, IHC & Yes & Yes & Xu et al. (2018) \\
\hline & & Human & GCs & RT-PCR & Yes & NA & Parikh et al. (2010) \\
\hline & & Human & GCs & Real-time PCR & Yes & NA & Thill et al. (2009) \\
\hline
\end{tabular}

GC, granulosa cell; IHC, immunohistochemistry; RNAseq, RNA sequencing; WB, Western blot; NA, not assessed. 


\section{VD signaling in the ovarian follicles}

The specific binding of VD3 to VDR in the ovary was demonstrated in hens by DNA cellulose chromatography, sucrose density gradient analysis, and saturation analysis (Dokoh et al. 1983), and later in fish (Xiphophorus helleri) by autoradiography (Bidman et al. 1997) (Table 1). The follicular expression of VDR was subsequently identified in various mammalian species (Table 1). VDR protein was localized predominantly in the oocyte of follicles at the early developmental stages, especially the primordial and primary follicles, as shown by immunohistochemistry staining in the caprine and rhesus macaque ovaries (Yao et al. 2017, $\mathrm{Xu}$ et al. 2018), though oocyte-specific staining could be further validated by including negative control tissue sections incubated with primary antibodies preabsorbed with blocking peptides. When follicle growth progresses to the preantral and antral stages, VDR expression becomes evident in GCs. VDR mRNA was detected in caprine and human GCs by RT-PCR and real-time PCR (Thill et al. 2009, Parikh et al. 2010, Yao et al. 2017). GC VDR immunostaining was localized in the ovary of rats, goats and rhesus macaques (Johnson et al. 1996, Yao et al. 2017, Xu et al. 2018). VDR protein was also detected by Western blot in GCs from caprine and porcine ovaries (Yao et al. 2017, Herian et al. 2018). The levels of VDR mRNA and protein expression appeared to correlate positively with antral follicle sizes (Wojtusik \& Johnson 2012, Yao et al. 2017). These data suggest that VD has the potential to act directly on the oocyte and GCs to maintain or alter the quiescent state of primordial follicles and to regulate the growth and maturation of growing follicles.

Recent in vitro evidence demonstrated that the VD ligand availability could directly impact follicular VDR expression. VD3 supplementation increased levels of VDR mRNA and protein in cultured caprine GCs (Yao et al. 2017). When isolated rhesus macaque follicles were cultured in the absence of VD, follicular VDR mRNA levels decreased compared with size-matched in vivo-developed follicles. With VD3 supplementation, $V D R$ mRNA expression in cultured follicles was restored to levels observed in follicles developed in vivo (Xu et al. 2018). VD3-enhanced VDR protein expression was also reported recently in cultured human ovarian surface epithelial cells (Pejovic et al. 2020). Although data in follicular cells are absent, research in mouse preosteoblastic cells and human lymphoblastoid cell lines indicated that the number of VDRE occupied by the VD3VDR-RXR complex were dynamically controlled by the VD ligand availability (Meyer et al. 2010, Ramagopalan et al. 2010). The VD3-VDR-RXR complex binding to VDRE was enhanced by VD3, which was associated with increased VDR occupancy and gene expression. Thus, VD could generate a positive feedback on VDR expression to enhance its endocrine and paracrine signaling in the ovary.

\section{VD in follicular development and oocyte maturation \\ VD-regulated follicular function in animal models}

Because VDR is expressed in various organs, including the hypothalamus, pituitary, ovary, oviduct, uterus and placenta (Stumpf \& Denny 1989), it is challenging to delineate the direct VD action on the ovarian follicles in vivo. In vitro studies are also limited due to the lack of adequate models to mimic the dynamic follicular development process.

\section{In vivo studies}

To date, a few studies have investigated VD in regulating ovarian function in vivo using animal models (Table 2). An early study reported that hens fed with a VD-deficient diet with calcium supplementation ceased laying and had decreased ovarian weight and plasma estradiol (E2)/progesterone (P) levels compared with those on a control diet (Ruschkowski \& Hart 1992). Consistently, although calcium was supplemented for proper calcium homeostasis, mice fed with a VD-deficient diet exhibited arrested follicular development and prolonged estrous cycles, with fewer mature oocytes retrieved following gonadotropin stimulation (Dicken et al. 2012). In addition, VDR-null mice showed ovarian insufficiency with impaired follicular development (Kinuta et al. 2000). E2 biosynthesis was disrupted due to decreased gene expression and activity of aromatase, which could not be fully recovered to the levels of control mice by calcium supplementation. Collectively, these data suggest an essential role of VD for proper follicular development and oocyte maturation, which is independent of calcium action. However, alterations in metabolism and function of organs other than the ovary, which compromise the overall health, cannot be ruled out in VD-deficient animals (Hadjadj et al. 2018). Recently, studies were conducted in polycystic ovary syndrome (PCOS) rat models to determine VD effects in the ovary. VD supplementation in the diet improved follicle viability and growth, as well as follicular E2 and $\mathrm{P}$ production (Behmanesh et al. 2019). Follicle morphology and follicular cell ultrastructure (e.g. cell junctions, endoplasmic reticulum, and lipid droplets), as well as serum testosterone levels, were ameliorated by VD3 injection (Kuyucu et al. 2020). The evidence supports trophic actions of VD on follicular health and function. However, it is difficult to elucidate the direct VD effect on follicles and enclosed oocytes in these in vivo studies because of the systemic effects generated by global VD manipulations, including altered 
Table 2 Vitamin D (VD)-regulated follicular function in animal models.

\begin{tabular}{|c|c|c|c|c|}
\hline Study setting & Species & Model & Outcomes & References \\
\hline \multirow[t]{5}{*}{ In vivo } & Hen & VD-deficient diet & $\begin{array}{l}\text { Laying ceased, } \downarrow \text { ovarian weight, } \downarrow \text { plasma E2 } \\
\text { and P }\end{array}$ & Ruschkowski \& Hart (1992) \\
\hline & Mouse & VD-deficient diet & $\begin{array}{l}\text { Arrested follicular development, prolonged } \\
\text { estrous cycles, } \downarrow \text { mature oocyte number }\end{array}$ & Dicken et al. (2012) \\
\hline & Mouse & $V D R$-knockout & $\begin{array}{l}\text { Impaired follicular development, } \\
\downarrow \text { aromatase expression and E2 production }\end{array}$ & Kinuta et al. (2000) \\
\hline & Rat & PCOS+VD supplementation & $\begin{array}{l}\text { Improved follicle viability and growth, } \\
\uparrow \text { serum E2 and P }\end{array}$ & Behmanesh et al. (2019) \\
\hline & Rat & PCOS+VD supplementation & $\begin{array}{l}\text { Improved follicle morphology and follicular } \\
\text { cell ultrastructure, } \downarrow \text { serum testosterone }\end{array}$ & Kuyucu et al. (2020) \\
\hline \multirow{4}{*}{$\begin{array}{l}\text { In vitro with VD3 } \\
\text { supplementation }\end{array}$} & Hen & GC culture & $\uparrow$ Cell proliferation & Wojtusik \& Johnson (2012) \\
\hline & Goat & GC culture & $\begin{array}{l}\uparrow \text { Cell proliferation, } \uparrow \mathrm{E} 2 \text { and } \mathrm{P} \text { production, } \\
\uparrow S T A R \text { and HSD } 3 B \text { mRNA levels }\end{array}$ & Yao et al. (2017) \\
\hline & Pig & GC culture & $\uparrow \mathrm{E} 2$ production, $\uparrow H S D 17 B 1$ mRNA levels & Hong et al. (2017) \\
\hline & Rhesus macaque & Follicle culture & $\begin{array}{l}\uparrow \text { Preantral follicle survival, } \uparrow \text { antral follicle } \\
\text { growth, improved E2 production and } \\
\text { oocyte maturation }\end{array}$ & Xu et al. (2016a), (2018) \\
\hline
\end{tabular}

$\downarrow$, decrease; $\uparrow$, increase; Statistically significant as $P<0.05$.

E2, estradiol; GC, granulosa cell; P, progesterone; PCOS, polycystic ovary syndrome; VD3, 1 $\alpha, 25$-dihydroxyvitamin D3.

gonadotropin levels (Behmanesh et al. 2019, Kuyucu et al. 2020).

\section{In vitro studies}

In vitro studies have attempted to assess the direct VD effects using cultured GCs and isolated follicles (Table 2). VD3 supplementation in the culture media promoted GC proliferation in hens and goats, as assessed by the MTT assay and flow-cytometric cell cycle analysis (Wojtusik \& Johnson 2012, Yao et al. 2017). E2 and/ or $\mathrm{P}$ production by cultured porcine and caprine GCs increased after VD3 treatment, which could be due to elevated expression of steroidogenic enzymes, including 3 3 -hydroxysteroid dehydrogenase and $17 \beta$-hydroxysteroid dehydrogenase 1 , as determined by real-time PCR (Hong et al. 2017, Yao et al. 2017). While GC culture is a relevant model for the cellular function of large antral follicles from which cells are collected, follicle culture approach offers an opportunity to study follicular activity at the preantral and small antral stages with intact oocyte-follicular cell interactions. Data from cultured rhesus macaque follicles revealed dose- and stage-dependent VD impact on follicular development and function. Low-dose $(25 \mathrm{pg} / \mathrm{mL}) \mathrm{VD} 3$ increased preantral follicle survival, whereas high-dose $(100 \mathrm{pg} / \mathrm{mL})$ VD3 enhanced antral follicle growth (Xu et al. 2016a). The VD3 doses bordered on the reference interval of systemic VD3 levels in humans (19.9-79.3 $\mathrm{pg} / \mathrm{mL}$; labcorp.com/tests/081091/calcitriol-1-25-di-o h-vitamin-d; Pasquali et al. 2015). VD3 supplementation also promoted E2 production and oocyte maturation of antral follicles developed in vitro (Xu et al. 2016a, 2018). The beneficial effects exerted by VD may be due to its anti-apoptotic and antioxidant actions, as well as by altering cell cycle activities (Yao et al. 2017). Thus, detailed studies are warranted to further understand the underlying mechanisms of VD in regulating folliculogenesis and oogenesis at specific follicular developmental stages.

\section{VD-regulated follicular function in humans}

Although research to assess VD effects on the ovary in women without reproductive disorders is limited, clinical studies examined the association between VD levels and ovarian function in patients with a history of infertility. Most of these studies were performed in the context of PCOS or assisted reproductive technology treatment, and the precursor form of VD (25-hydroxyvitamin D3) was often the VD metabolite analyzed in the blood or follicular fluid.

\section{Clinical trials}

Primordial follicles represent the dormant follicle pool in the ovary, that is, the 'ovarian reserve' (Wallace \& Kelsey 2010). Many clinical studies did not identify any correlations between serum VD levels and ovarian reserve parameters (Table 3 ). A prospective crosssectional study and a retrospective cohort study reported that serum VD levels were not associated with ovarian reserve in women who received infertility treatment (Drakopoulos et al. 2017, Shapiro et al. 2018). When serum VD3 levels were analyzed retrospectively in oocyte donors, a high prevalence of VD insufficiency did not impair ovarian reserve (Fabris et al. 2017). However, an observational prospective study suggested that severely low systemic VD levels might be associated with a reduced ovarian reserve in VD-deficient patients (Arefi et al. 2018). An inverse relationship between serum VD levels and ovarian reserve was also identified in patients with uterine fibroids (Jukic et al. 2015). The caveat of current clinical research is that only indirect 
markers of ovarian reserve were evaluated, that is, follicle-stimulating hormone (FSH) and anti-Müllerian hormone (AMH) levels and antral follicle count, which represent the growing follicle pool, particularly antral follicles, instead of the dormant primordial follicles. Direct assessment on the number and quality of primordial follicles is needed to determine the true ovarian reserve associated with VD status, which is challenging in human studies.

To date, clinical data on VD-associated follicular growth and oocyte maturation yielded equivocal or inconsistent outcomes (Table 3). A number of studies supported the trophic role of VD in promoting follicular development and function, as well as oocyte maturation and competence, during the spontaneous menstrual cycle and IVF cycle. VD deficiency was associated with prolonged follicular phase and overall menstrual cycle length in reproductive-aged women in a prospective cohort study (Jukic et al. 2018). Secondary analysis of a multicenter randomized controlled trial suggested that VD-deficient patients with PCOS were less likely to ovulate following ovulation induction compared with those with sufficient circulating levels of VD (Pal et al. 2016). Calcitriol (VD3) supplementation improved spontaneous ovulation of patients with PCOS in a randomized placebo-controlled trial (Bonakdaran et al. 2012). PCOS patients with documented chronic anovulation resumed normal menstrual cycles after ergocalciferol (vitamin D2) repletion along with calcium therapy (Thys-Jacobs et al. 1999). Serum VD concentrations correlated positively with the number of mature oocytes retrieved and oocyte fertilization rates in patients undergoing the IVF cycle in prospective studies, which was suggested to involve anti-inflammatory

Table 3 Vitamin D (VD)-regulated follicular function in humans.

\begin{tabular}{|c|c|c|c|c|}
\hline \multicolumn{2}{|c|}{$\begin{array}{l}\text { Study setting/ patients } \\
\text { Clinical trial }\end{array}$} & VD status or treatment & Outcomes & References \\
\hline & PCOS & VD deficiency & $\downarrow$ Ovulation by induction & Pal et al. (2016) \\
\hline & PCOS & Calcitriol supplementation & $\uparrow S$ pontaneous ovulation & Bonakdaran et al. (2012) \\
\hline & PCOS & $\begin{array}{l}\text { Ergocalciferol and calcium } \\
\text { supplementation }\end{array}$ & Resumption of normal menstrual cycles & Thys-Jacobs et al. (1999) \\
\hline & IVF & VD deficiency & $\begin{array}{l}\text { Serum VD levels were not associated with serum } \\
\text { AMH concentrations or AFC }\end{array}$ & Drakopoulos et al. (2017) \\
\hline & IVF & VD deficiency & $\begin{array}{l}\text { Serum VD levels were not associated with serum } \\
\text { AMH or FSH concentrations }\end{array}$ & Shapiro et al. (2018) \\
\hline & IVF & VD deficiency & Serum VD levels correlated positively with AFC & Arefi et al. (2018) \\
\hline & IVF & Normal & $\begin{array}{l}\text { High serum VD levels were associated with } \\
\text { increased fertilization rates }\end{array}$ & Abadia et al. (2016) \\
\hline & IVF & VD deficiency and insufficiency & $\begin{array}{l}\text { High serum VD levels were associated with } \\
\text { increased fertilization rates }\end{array}$ & Liu et al. (2019) \\
\hline & IVF & VD deficiency and insufficiency & $\begin{array}{l}\text { High serum VD levels were associated with } \\
\text { increased number of oocytes retrieved and } \\
\text { fertilization rates }\end{array}$ & Wu et al. (2018) \\
\hline & IVF & VDR polymorphism (Taql) & $\downarrow$ AFC & Reginatto et al. (2018) \\
\hline & IVF & Normal & $\begin{array}{l}\text { Low FF VD levels were associated with high AFC } \\
\text { and serum E2 concentrations }\end{array}$ & Antunes et al. (2018) \\
\hline & IVF & VD deficiency & $\begin{array}{l}\text { Low FF VD levels were associated with high } \\
\text { fertilization rates }\end{array}$ & Ciepiela et al. (2018) \\
\hline & IVF & VD deficiency and insufficiency & $\begin{array}{l}\text { Serum VD levels were not associated with } \\
\text { fertilization rates }\end{array}$ & Firouzabadi et al. (2014) \\
\hline & IVF & VD deficiency and insufficiency & $\begin{array}{l}\text { Serum VD levels were not associated with the } \\
\text { number of oocytes retrieved, fertilization rates, or } \\
\text { embryo quality }\end{array}$ & Rudick et al. (2012) \\
\hline & Uterine fibroid & VD deficiency and insufficiency & $\begin{array}{l}\text { Serum VD levels correlated negatively with urinary } \\
\text { FSH concentrations }\end{array}$ & Jukic et al. (2015) \\
\hline & Oocyte donor & VD deficiency and insufficiency & $\begin{array}{l}\text { Serum VD levels were not associated with serum } \\
\text { AMH concentrations }\end{array}$ & Fabris et al. (2017) \\
\hline & Oocyte donor & VD deficiency and insufficiency & $\begin{array}{l}\text { Serum VD levels were not associated with the } \\
\text { number of oocytes retrieved, fertilization rates, or } \\
\text { embryo quality }\end{array}$ & Banker et al. (2017) \\
\hline & Healthy & VD deficiency and insufficiency & $\begin{array}{l}\text { Serum VD levels correlated negatively with } \\
\text { follicular phase and menstrual cycle lengths }\end{array}$ & Jukic et al. (2015) \\
\hline \multicolumn{5}{|l|}{ GC culture } \\
\hline & IVF & VD3 supplementation & $\uparrow \mathrm{P}$ production, $\uparrow H S D 3 B$ mRNA levels & Merhi et al. (2014) \\
\hline & IVF & VD3 supplementation & $\downarrow$ AGE adverse effects on steroidogenesis & Merhi et al. (2018) \\
\hline & IVF & VD3 supplementation & $\begin{array}{l}\uparrow E 2 \text { and } P \text { production, } \uparrow \text { insulin inhibitory effect on } \\
\text { IGFBP1 production }\end{array}$ & Parikh et al. (2010) \\
\hline
\end{tabular}

$\uparrow$, increase; $\downarrow$, decrease; Statistically significant as $P<0.05$.

AFC, antral follicle count; AGE, advanced glycation end products; $\mathrm{AMH}$, anti-Müllerian hormone; E2, estradiol; FF, follicular fluid; FSH, follicle-stimulating hormone; GC, granulosa cell; 
effects of VD (Abadia et al. 2016, Wu et al. 2018, Liu et al. 2019). A VDR polymorphism (Taql) resulted in decreased antral follicle counts in patients receiving ovarian stimulation (Reginatto et al. 2018). However, contradictory findings were reported in studies with the similar IVF setting, wherein high follicular fluid VD levels were associated with low antral follicle count, serum E2 concentrations, and oocyte fertilization rates (Antunes et al. 2018, Ciepiela et al. 2018). In addition, some studies did not identify a significant relationship between serum or follicular fluid VD levels and the IVF outcomes, such as the number of oocytes retrieved, oocyte fertilization rates, and embryo quality in either patients receiving infertility treatment or oocyte donors (Rudick et al. 2012, Firouzabadi et al. 2014, Banker et al. 2017). The controversial results are likely due to the heterogeneity of patient background and medical treatment protocols, as well as the fact that, in most cases, only the precursor form of VD (25-hydroxyvitamin D3) was analyzed. There is a lack of information as to levels of bioactive VD3 in the follicular fluid or follicular and oocyte VDR expression leading to downstream actions via ligand-receptor binding.

\section{In vitro studies}

Similar to animal studies, in vitro experiments have been conducted mainly in cultured GCs (mural or cumulus GCs) from large antral follicles in patients undergoing IVF, yielding consistent results in terms of VD-enhanced GC function in steroid production (Table 3). VD3 supplementation stimulated E2 and/or $\mathrm{P}$ production directly by promoting the expression of steroidogenic enzymes, for example, $3 \beta$-hydroxysteroid dehydrogenase (Merhi et al. 2014), as determined by real-time PCR, or indirectly by altering the actions of steroidogenic-related factors, for example, advanced glycation end products and insulin-like growth factor (Parikh et al. 2010, Merhi et al. 2018). Data suggest that VD supports ovarian steroidogenesis, which is essential for follicular development and oocyte maturation. However, data on steroidogenic enzyme protein expression and activity are limited. VD effects have not been studied in intact human preantral from small antral follicles in vitro. Additional investigations are needed to evaluate the relationship between VD metabolic/ signaling components and follicular function in humans.

\section{Species differences in VD-regulated follicular signaling pathways}

While many VD-regulated molecular and cellular processes during follicular development and oocyte maturation are similar in animal models and humans, species differences are observed involving key regulatory factors and signaling pathways. For example, studies using GC culture yielded inconclusive results Reproduction (2021) 161 R129-R137 on VD-regulated expression of $\mathrm{FSH}$ receptor (FSHR) and AMH signaling pathway components. While VD3 supplementation increased FSHR mRNA levels in hens (Wojtusik \& Johnson 2012), it did not alter FSHR expression in pigs and reduced the mRNA and/or protein expression of FSHR in goats and humans (Merhi et al. 2014, Hong et al. 2017, Yao et al. 2017). Although VD3 supplementation decreased $A M H$ mRNA levels in hens (Wojtusik \& Johnson 2012), the mRNA and/or protein expression of $\mathrm{AMH}$ ligand was not affected by VD3 treatment in pigs, goats or humans (Merhi et al. 2014, Hong et al. 2017, Yao et al. 2017). Instead, VD3 supplementation led to reduced $\mathrm{AMH}$-specific receptor expression in goats and humans (Merhi et al. 2014, Yao et al. 2017). It is consistent in terms of the stimulatory effects of VD on E2 and P production in cultured GCs. However, the alterations in steroidogenic enzyme expression patterns by VD3 supplementation vary between different species. For example, the mRNA levels of StAR protein and aromatase (CYP19A1) increased in goats and pigs, respectively, but remained unchanged in humans after VD3 treatment (Merhi et al. 2014, Hong et al. 2017, Yao et al. 2017). It appears that VD actions on regulating follicular cell function could be speciesspecific.

\section{Involvement of VD in regulating mitochondrial biogenesis and function}

Mitochondria participate in various cellular processes, including ATP synthesis, calcium signaling, reactive oxygen species production, and apoptosis, which have a critical impact on follicular development and oocyte maturation/competence (May-Panloup et al. 2016). Recently, emerging studies intend to investigate VD actions on mitochondrial biogenesis and function, particularly in cultured rodent GCs. When rat GCs were treated with VD3, mitochondrial biogenesisrelated protein expression was increased, which in turn promoted cellular oxygen consumption and ATP production (Lee et al. 2019). VD3 supplementation in the culture media increased mitochondrial DNA copy number, biogenesis and membrane integrity, as well as upregulated gene expression of antioxidant and antiapoptotic factors, in GCs from a PCOS mouse model (Safaei et al. 2020a, b). Although data are not available for VD-regulated mitochondrial biogenesis and function in the oocyte, these data provide a foundation for studies in vivo and in other animal models or humans to further elucidate VD-regulated mitochondrial activity during folliculogenesis and oogenesis.

\section{Conclusions and future perspectives}

Although VD metabolism and signaling pathway are well-known, their existence and importance during folliculogenesis and oogenesis remain obscure.

https://rep.bioscientifica.com 
Sufficient VD action appears to be important for the coordinated development of ovarian follicles with improved ovarian steroidogenic function and oocyte maturation. However, it has been challenging to study the direct VD effects in the ovary due to the fact that actions of VD as an endocrine and paracrine factor are highly context-dependent (Stumpf \& Denny 1989, Xu et al. 2018). Species and follicular developmental stages, as well as VD metabolite forms, doses and treatment interval, need to be carefully considered during the experimental design. Therefore, adequate animal models are needed for performing well-controlled in vivo and in vitro studies to increase our knowledge surrounding the dynamics of follicular VD metabolites and expression of VDR, VD-regulated follicular development and oocyte maturation, as well as the underlying molecular and cellular mechanisms of VD action in the ovary.

In clinical studies, the correlation between VD levels in the circulation and the follicle or oocyte parameters may vary significantly among patients who are different in VD metabolism and signaling due to diverse physiological and pathological conditions. Follicular development and function may be evaluated more effectively in a relatively homogeneous patient population under a well-controlled experimental design. Although there is a general consensus that the total precursor form of VD (25-hydroxyvitamin D3) is the biochemical marker for nutritional VD status, the value may not reflect the bioavailable levels of VD in the ovary. VD is transported to target tissues by binding to high-affinity carrier proteins in the circulation, such as VD binding protein (Bikle et al. 2017). Because VD binding protein polymorphisms, which vary in humans with different ethnic background, affect the binding affinity to VD (Constans et al. 1985, Arnaud and Constans 1993), VD status may be better assessed by calculating bioavailable VD based on levels of total VD and carrier proteins (Fabris et al. 2014). In addition, it is known that serum VD levels vary significantly throughout the year (Tjellesen \& Christiansen 1983). Therefore, correction for seasonal variation during data analysis may enhance the validity of study results (Hartwell et al. 1990). Follicular fluid levels of the bioactive form VD3 and the inactive VD metabolite (24,25-dihydroxyvitamin D3), as well as the expression of follicular VDR, may provide further information on VD-exerted biological activities in the ovary (Franasiak et al. 2017). Thus, the association between VD status in patients and their ovarian-related reproductive outcomes warrants further investigation.

In summary, collective evidence suggests a potential role of VD in ovarian follicular development and function from primordial follicle activation to ovulation to generate mature oocytes. VD effects on follicular cells and the oocyte could be direct via regulating its downstream factors or indirect via mediating gonadotropin actions. A comprehensive understanding of VD-regulated folliculogenesis and oogenesis will provide critical insight into the impact of VD in female reproductive health. Importantly, VD supplementation may have potential therapeutic benefits on improving endocrine function and fertility in women.

\section{Declaration of interest}

The authors declare that there is no conflict of interest that could be perceived as prejudicing the impartiality of this review.

\section{Funding}

This work was supported by the National Institutes of Health (NIH) Office of the Director (grant number P51OD011092); the NIH National Institute of General Medical Sciences (grant numbers UL1GM118964, RL5GM118963 and TL4GM118965). The content is solely the responsibility of the authors and does not necessarily represent the official views of the NIH.

\section{Author contribution statement}

$\mathrm{F} X$ reviewed literatures and wrote the manuscript. S W and $O \mathrm{G}$ reviewed literatures and revised the manuscript. J $X$ conceived the topic, reviewed literatures, and wrote the manuscript.

\section{References}

Abadia L, Gaskins AJ, Chiu YH, Williams PL, Keller M, Wright DL, Souter I, Hauser R, Chavarro JE \& Environment and Reproductive Health Study Team 2016 Serum 25-hydroxyvitamin D concentrations and treatment outcomes of women undergoing assisted reproduction. American Journal of Clinical Nutrition 104 729-735. (https://doi.org/10.3945/ ajcn.115.126359)

Antunes RA, Mancebo ACA, Reginatto MW, Deriquehem VAS, Areas P, Bloise E, Chiamolera MI, Ribeiro GCM, Carvalho ARS, Souza MCB et al. 2018 Lower follicular fluid vitamin D concentration is related to a higher number of large ovarian follicles. Reproductive Biomedicine Online 36 277-284. (https://doi.org/10.1016/j.rbmo.2017.12.010)

Arefi S, Khalili G, Iranmanesh H, Farifteh F, Hosseini A, Fatemi HM \& Lawrenz B 2018 Is the ovarian reserve influenced by vitamin D deficiency and the dress code in an infertile Iranian population? Journal of Ovarian Research 11 62. (https://doi.org/10.1186/s13048-018-04357)

Arnaud J \& Constans J 1993 Affinity differences for vitamin D metabolites associated with the genetic isoforms of the human serum carrier protein (DBP). Human Genetics 92 183-188. (https://doi.org/10.1007/ BF00219689)

Banker M, Sorathiya D \& Shah S 2017 Vitamin D deficiency does not influence reproductive outcomes of IVF-ICSI: a study of oocyte donors and recipients. Journal of Human Reproductive Sciences 10 79-85. (https://doi.org/10.4103/jhrs.JHRS_117_16)

Behmanesh N, Abedelahi A, Charoudeh HN \& Alihemmati A 2019 Effects of vitamin D supplementation on follicular development, gonadotropins and sex hormone concentrations, and insulin resistance in induced polycystic ovary syndrome. Turkish Journal of Obstetrics and Gynecology 16 143-150. (https://doi.org/10.4274/tjod.galenos.2019.46244)

Bidman HJ, Radu I \& Stumpf WE 1997 Aspects of 1,25-dihydroxyvitamin D3 binding sites in fish: an autoradiographic study. Romanian Journal of Morphology and Embryology 43 91-101. 
Bièche I, Narjoz C, Asselah T, Vacher S, Marcellin P, Lidereau R, Beaune $P$ \& Waziers I 2007 Reverse transcriptase-PCR quantification of mRNA levels from cytochrome (CYP)1, CYP2 and CYP3 families in 22 different human tissues. Pharmacogenetics and Genomics 17 731-742. (https:// doi.org/10.1097/FPC.0b013e32810f2e58)

Bikle D, Bouillon R, Thadhani R \& Schoenmakers I 2017 Vitamin D metabolites in captivity? Should we measure free or total $25(\mathrm{OH}) \mathrm{D}$ to assess vitamin D status? Journal of Steroid Biochemistry and Molecular Biology 173 105-116. (https://doi.org/10.1016/j.jsbmb.2017.01.007)

Bikle DD 2014 Vitamin D metabolism, mechanism of action, and clinical applications. Chemistry and Biology 21 319-329. (https://doi. org/10.1016/j.chembiol.2013.12.016)

Bonakdaran S, Mazloom Khorasani Z, Davachi B \& Mazloom Khorasani J 2012 The effects of calcitriol on improvement of insulin resistance, ovulation and comparison with metformin therapy in PCOS patients: a randomized placebo- controlled clinical trial. Iranian Journal of Reproductive Medicine 10 465-472.

Ciepiela P, Dulęba AJ, Kowaleczko E, Chełstowski K \& Kurzawa R 2018 Vitamin D as a follicular marker of human oocyte quality and a serum marker of in vitro fertilization outcome. Journal of Assisted Reproduction and Genetics 35 1265-1276. (https://doi.org/10.1007/s10815-018-1179-4)

Constans J, Hazout S, Garruto RM, Gajdusek DC \& Spees EK 1985 Population distribution of the human vitamin D binding protein: anthropological considerations. American Journal of Physical Anthropology 68 107-122. (https://doi.org/10.1002/ajpa.1330680110)

Dicken CL, Israel DD, Davis JB, Sun Y, Shu J, Hardin J \& Neal-Perry G 2012 Peripubertal vitamin D(3) deficiency delays puberty and disrupts the estrous cycle in adult female mice. Biology of Reproduction 8751. (https://doi.org/10.1095/biolreprod.111.096511)

Dokoh S, Donaldson CA, Marion SL, Pike JW \& Haussler MR 1983 The ovary: a target organ for 1,25-dihydroxyvitamin D3. Endocrinology 112 200-206. (https://doi.org/10.1210/endo-112-1-200)

Drakopoulos P, van de Vijver A, Schutyser V, Milatovic S, Anckaert E, Schiettecatte J, Blockeel C, Camus M, Tournaye H \& Polyzos NP 2017 The effect of serum vitamin $D$ levels on ovarian reserve markers: a prospective cross-sectional study. Human Reproduction 32 208-214. (https://doi.org/10.1093/humrep/dew304)

Fabris A, Pacheco A, Cruz M, Puente JM, Fatemi H \& Garcia-Velasco JA 2014 Impact of circulating levels of total and bioavailable serum vitamin D on pregnancy rate in egg donation recipients. Fertility and Sterility 102 1608-1612. (https://doi.org/10.1016/j.fertnstert.2014.08.030)

Fabris AM, Cruz M, Iglesias C, Pacheco A, Patel A, Patel J, Fatemi H \& García-Velasco JA 2017 Impact of vitamin D levels on ovarian reserve and ovarian response to ovarian stimulation in oocyte donors. Reproductive Biomedicine Online 35 139-144. (https://doi. org/10.1016/j.rbmo.2017.05.009)

Firouzabadi RD, Rahmani E, Rahsepar M \& Firouzabadi MM 2014 Value of follicular fluid vitamin $\mathrm{D}$ in predicting the pregnancy rate in an IVF program. Archives of Gynecology and Obstetrics 289 201-206. (https:// doi.org/10.1007/s00404-013-2959-9)

Fischer D, Thomé M, Becker S, Cordes T, Diedrich K, Friedrich M \& Thill M 2009 25-Hydroxyvitamin D3 1alpha-hydroxylase splice variants in benign and malignant ovarian cell lines and tissue. Anticancer Research $293627-3633$.

Franasiak JM, Lara EE \& Pellicer A 2017 Vitamin D in human reproduction. Current Opinion in Obstetrics and Gynecology 29 189-194. (https://doi. org/10.1097/GCO.0000000000000375)

Gougeon A 1996 Regulation of ovarian follicular development in primates: facts and hypotheses. Endocrine Reviews 17 121-155. (https://doi. org/10.1210/edrv-17-2-121)

Hadjadj L, Várbíró S, Horváth EM, Monori-Kiss A, Pál É, Karvaly GB, HeinzImann A, Magyar A, Szabó I, Sziva RE et al. 2018 Insulin resistance in an animal model of polycystic ovary disease is aggravated by vitamin D deficiency: vascular consequences. Diabetes and Vascular Disease Research 15 294-301. (https://doi.org/10.1177/1479164118758580)

Hartwell D, Riis BJ \& Christiansen C 1990 Changes in vitamin D metabolism during natural and medical menopause. Journal of Clinical Endocrinology and Metabolism 71 127-132. (https://doi.org/10.1210/ jcem-71-1-127)

Haussler MR, Jurutka PW, Mizwicki M \& Norman AW 2011 Vitamin D receptor (VDR)-mediated actions of $1 \alpha, 25(\mathrm{OH})_{2}$ vitamin $\mathrm{D}_{3}$ : genomic and non-genomic mechanisms. Best Practice and Research. Clinical
Endocrinology and Metabolism 25 543-559. (https://doi.org/10.1016/j. beem.2011.05.010)

Herian M, Luck MR \& Grzesiak M 2018 The influence of testosterone on the expression and function of vitamin $\mathrm{D}(3)$ receptor (VDR) protein in the porcine ovarian follicle. Physiological Research 67 515-519. (https:// doi.org/10.33549/physiolres.933762)

Hong SH, Lee JE, An SM, Shin YY, Hwang DY, Yang SY, Cho SK \& An BS 2017 Effect of vitamin D3 on biosynthesis of estrogen in porcine granulosa cells via modulation of steroidogenic enzymes. Toxicological Research 33 49-54. (https://doi.org/10.5487/TR.2017.33.1.049)

Hossein-nezhad A \& Holick MF 2013 Vitamin D for health: a global perspective. Mayo Clinic Proceedings 88 720-755. (https://doi. org/10.1016/j.mayocp.2013.05.011)

Irani M \& Merhi Z 2014 Role of vitamin D in ovarian physiology and its implication in reproduction: a systematic review. Fertility and Sterility 102 460-468.e3. (https://doi.org/10.1016/j.fertnstert.2014.04.046)

Johnson JA, Grande JP, Roche PC \& Kumar R 1996 Immunohistochemical detection and distribution of the 1,25-dihydroxyvitamin D3 receptor in rat reproductive tissues. Histochemistry and Cell Biology 105 7-15. (https://doi.org/10.1007/BF01450873)

Jukic AMZ, Steiner AZ \& Baird DD 2015 Association between serum 25-hydroxyvitamin $\mathrm{D}$ and ovarian reserve in premenopausal women. Menopause 22 312-316. (https://doi.org/10.1097/ GME.0000000000000312)

Jukic AMZ, Wilcox AJ, McConnaughey DR, Weinberg CR \& Steiner AZ 2018 25-Hydroxyvitamin D and long menstrual cycles in a prospective cohort study. Epidemiology 29 388-396. (https://doi.org/10.1097/ EDE.0000000000000804)

Kinuta K, Tanaka H, Moriwake T, Aya K, Kato S \& Seino Y 2000 Vitamin $\mathrm{D}$ is an important factor in estrogen biosynthesis of both female and male gonads. Endocrinology 141 1317-1324. (https://doi.org/10.1210/ endo.141.4.7403)

Kuyucu Y, Sencar L, Tap Ö \& Mete UÖ 2020 Investigation of the effects of vitamin D treatment on the ovarian $\mathrm{AMH}$ receptors in a polycystic ovary syndrome experimental model: an ultrastructural and immunohistochemical study. Reproductive Biology 20 25-32. (https:// doi.org/10.1016/j.repbio.2020.01.001)

Lee CT, Wang JY, Chou KY \& Hsu MI 2019 1,25-Dihydroxyvitamin D 3 modulates the effects of sublethal BPA on mitochondrial function via activating Pl3K-Akt pathway and $17 \beta$-estradiol secretion in rat granulosa cells. Journal of Steroid Biochemistry and Molecular Biology 185 200-211. (https://doi.org/10.1016/j.jsbmb.2018.09.002)

Liu X, Zhang W, Xu Y, Chu Y, Wang X, Li Q, Ma Z, Liu Z \& Wan Y 2019 Effect of vitamin $\mathrm{D}$ status on normal fertilization rate following in vitro fertilization. Reproductive Biology and Endocrinology : RB\&E 1759. (https://doi.org/10.1186/s12958-019-0500-0)

May-Panloup P, Boucret L, Chao de la Barca JM, Desquiret-Dumas V, Ferré-L'Hotellier V, Morinière $C$, Descamps $P$, Procaccio $V$ \& Reynier $P$ 2016 Ovarian ageing: the role of mitochondria in oocytes and follicles. Human Reproduction Update 22 725-743. (https://doi.org/10.1093/ humupd/dmw028)

Merhi Z, Buyuk E \& Cipolla MJ 2018 Advanced glycation end products alter steroidogenic gene expression by granulosa cells: an effect partially reversible by vitamin D. Molecular Human Reproduction 24 318-326. (https://doi.org/10.1093/molehr/gay014)

Merhi Z, Doswell A, Krebs K \& Cipolla M 2014 Vitamin D alters genes involved in follicular development and steroidogenesis in human cumulus granulosa cells. Journal of Clinical Endocrinology and Metabolism 99 E1137-E1145. (https://doi.org/10.1210/jc.2013-4161)

Meyer MB, Goetsch PD \& Pike JW 2010 Genome-wide analysis of the VDR/ RXR cistrome in osteoblast cells provides new mechanistic insight into the actions of the vitamin D hormone. Journal of Steroid Biochemistry and Molecular Biology 121 136-141. (https://doi.org/10.1016/j. jsbmb.2010.02.011)

Pal L, Zhang H, Williams J, Santoro NF, Diamond MP, Schlaff WD, Coutifaris C, Carson SA, Steinkampf MP, Carr BR et al. 2016 Vitamin D status relates to reproductive outcome in women with polycystic ovary syndrome: secondary analysis of a multicenter randomized controlled trial. Journal of Clinical Endocrinology and Metabolism 101 3027-3035. (https://doi.org/10.1210/jc.2015-4352)

Parikh G, Varadinova M, Suwandhi P, Araki T, Rosenwaks Z, Poretsky L \& Seto-Young D 2010 Vitamin D regulates steroidogenesis and insulin- 
like growth factor binding protein-1 (IGFBP-1) production in human ovarian cells. Hormone and Metabolic Research 42 754-757. (https:// doi.org/10.1055/s-0030-1262837)

Pasquali M, Tartaglione L, Rotondi S, Muci ML, Mandanici G, Farcomeni A, Marangella M \& Mazzaferro S 2015 Calcitriol/calcifediol ratio: an indicator of vitamin D hydroxylation efficiency? BBA Clinical 3 251-256. (https://doi.org/10.1016/j.bbacli.2015.03.004)

Pejovic T, Joshi S, Campbell S, Thisted S, Xu F \& Xu J 2020 Association between vitamin $\mathrm{D}$ and ovarian cancer development in BRCA1 mutation carriers. Oncotarget 11 4104-4114. (https://doi.org/10.18632/ oncotarget.27803)

Potashnik G, Lunenfeld E, Levitas E, Itskovitz J, Albutiano S, Yankowitz N, Sonin Y, Levy J, Glezerman M \& Shany S 1992 The relationship between endogenous oestradiol and vitamin D3 metabolites in serum and follicular fluid during ovarian stimulation for in-vitro fertilization and embryo transfer. Human Reproduction 7 1357-1360. (https://doi. org/10.1093/oxfordjournals.humrep.a137573)

Ramagopalan SV, Heger A, Berlanga AJ, Maugeri NJ, Lincoln MR, Burrell A, Handunnetthi L, Handel AE, Disanto G, Orton SM et al. 2010 A ChIP-seq defined genome-wide map of vitamin D receptor binding: associations with disease and evolution. Genome Research 20 1352-1360. (https://doi.org/10.1101/gr.107920.110)

Reginatto MW, Pizarro BM, Antunes RA, Mancebo ACA, Hoffmann L, Fernandes P, Areas P, Chiamolera MI, Silva R, Souza MDCB et al. 2018 Vitamin $D$ receptor Taql polymorphism is associated with reduced follicle number in women utilizing assisted reproductive technologies. Frontiers in Endocrinology 9 252. (https://doi.org/10.3389/fendo.2018.00252)

Rudick B, Ingles S, Chung K, Stanczyk F, Paulson R \& Bendikson K 2012 Characterizing the influence of vitamin D levels on IVF outcomes. Human Reproduction 27 3321-3327. (https://doi.org/10.1093/humrep/ des280)

Ruschkowski SR \& Hart LE 1992 lonic and endocrine characteristics of reproductive failure in calcium-deficient and vitamin D-deficient laying hens. Poultry Science 71 1722-1732. (https://doi.org/10.3382/ ps.0711722)

Safaei Z, Bakhshalizadeh S, Nasr-Esfahani MH, Sene AA, Najafzadeh V, Soleimani M \& Shirazi R 2020a Vitamin D3 affects mitochondrial biogenesis through mitogen-activated protein kinase in polycystic ovary syndrome mouse model. Journal of Cellular Physiology 235 6113-6126. (https://doi.org/10.1002/jcp.29540)

Safaei Z, Bakhshalizadeh S, Nasr Esfahani MH, Sene AA, Najafzadeh V, Soleimani M \& Shirazi R $2020 b$ Effect of vitamin D3 on mitochondrial biogenesis in granulosa cells derived from polycystic ovary syndrome. International Journal of Fertility and Sterility 14 143-149. (https://doi. org/10.22074/ijfs.2020.6077)

Shapiro AJ, Darmon SK, Barad DH, Gleicher N \& Kushnir VA 2018 Vitamin D levels are not associated with ovarian reserve in a group of infertile women with a high prevalance of diminished ovarian reserve. Fertility and Sterility 110 761-766.e1. (https://doi.org/10.1016/j. fertnstert.2018.05.005)

Stumpf WE \& Denny ME 1989 Vitamin D (soltriol), light, and reproduction. American Journal of Obstetrics and Gynecology 161 1375-1384. (https://doi.org/10.1016/0002-9378(89)90699-6)

Thill M, Becker S, Fischer D, Cordes T, Hornemann A, Diedrich K, Salehin D \& Friedrich M 2009 Expression of prostaglandin metabolising enzymes COX-2 and 15-PGDH and VDR in human granulosa cells. Anticancer Research 29 3611-3618.
Thys-Jacobs S, Donovan D, Papadopoulos A, Sarrel P \& Bilezikian JP 1999 Vitamin D and calcium dysregulation in the polycystic ovarian syndrome. Steroids 64 430-435. (https://doi.org/10.1016/s0039-128x(99)00012-4)

Tjellesen L \& Christiansen C 1983 Vitamin D metabolites in normal subjects during one year. A longitudinal study. Scandinavian Journal of Clinical and Laboratory Investigation 43 85-89. (https://doi. org/10.3109/00365518309168226)

Verstuyf A, Carmeliet G, Bouillon R \& Mathieu C 2010 Vitamin D: a pleiotropic hormone. Kidney International 78 140-145. (https://doi. org/10.1038/ki.2010.17)

Wagner CL, Taylor SN, Dawodu A, Johnson DD \& Hollis BW 2012 Vitamin $\mathrm{D}$ and its role during pregnancy in attaining optimal health of mother and fetus. Nutrients 4 208-230. (https://doi.org/10.3390/nu4030208)

Wallace WH \& Kelsey TW 2010 Human ovarian reserve from conception to the menopause. PLOS ONE 5 e8772. (https://doi.org/10.1371/journal. pone.0008772)

Wojtusik J \& Johnson PA 2012 Vitamin D regulates anti-Mullerian hormone expression in granulosa cells of the hen. Biology of Reproduction 8691. (https://doi.org/10.1095/biolreprod.111.094110)

Wu L, Kwak-Kim J, Zhang R, Li Q, Lu FT, Zhang Y, Wang HY, Zhong LW \& Liu YS 2018 Vitamin D level affects IVF outcome partially mediated via Th/Tc cell ratio. American Journal of Reproductive Immunology $\mathbf{8 0}$ e13050. (https://doi.org/10.1111/aji.13050)

Xu J, Hennebold JD \& Seifer DB 2016a Direct vitamin D3 actions on rhesus macaque follicles in three-dimensional culture: assessment of follicle survival, growth, steroid, and antiMüllerian hormone production. Fertility and Sterility 106 1815-1820.e1. (https://doi.org/10.1016/j. fertnstert.2016.08.037)

Xu J, Lawson MS, Xu F, Du Y, Tkachenko OY, Bishop CV, Pejovic-Nezhat L, Seifer DB \& Hennebold JD 2018 Vitamin D3 regulates follicular development and intrafollicular vitamin D biosynthesis and signaling in the primate ovary. Frontiers in Physiology 9 1600. (https://doi. org/10.3389/fphys.2018.01600)

Xu J, Xu F, Letaw JH, Park BS, Searles RP \& Ferguson BM 2016b AntiMüllerian hormone is produced heterogeneously in primate preantral follicles and is a potential biomarker for follicle growth and oocyte maturation in vitro. Journal of Assisted Reproduction and Genetics 33 1665-1675. (https://doi.org/10.1007/s10815-016-0804-3)

Yao X, Zhang G, Guo Y, Ei-Samahy M, Wang S, Wan Y, Han L, Liu Z, Wang F \& Zhang Y 2017 Vitamin D receptor expression and potential role of vitamin $\mathrm{D}$ on cell proliferation and steroidogenesis in goat ovarian granulosa cells. Theriogenology 102 162-173. (https://doi. org/10.1016/j.theriogenology.2017.08.002)

Zhao G, Ford ES, Tsai J, Li C \& Croft JB 2012 Factors associated with vitamin D deficiency and inadequacy among women of childbearing age in the United States. ISRN Obstetrics and Gynecology 2012691486. (https://doi.org/10.5402/2012/691486)

Received 14 November 2020

First decision 4 January 2020

Revised Manuscript received 2 March 2021

Accepted 8 April 2021 